10. Red deIndicadores deCiencia y Tecnología Iberoamericana eInteramericana. Recursos humanos. Personal por género. [Accessed on: December 12 $\left.{ }^{\text {th }}, 2016\right]$. Available at: http:/ / db.ricyt.org/query/AR,BO,CL,CO,CR,CU,EC,ES,GT,HN,NI,PA, PR,PT,PY,SV,TT,UY,VE/1990\%2C2014/ PERSOPFGENPER.

11. Franchi A, Kochen S, Maffía D, et al. Evolución de la situación de las Mujeres en el sector de Ciencia y Tecnología en Argentina (1998-2013). X Congreso Iberoamericano de Ciencia, Tecnología y Género. 28 a 30 de octubre de 2014. Asunción, Paraguay; 2014.

12. Macaluso $B$, Larivière $V$, Sugimoto $T$, et al. Is Science Built on the Shoulders of Women? A Study of Gender Differences in Contributorship. Acad Med 2016;91(8):1136-42.

13. Fridner A, Norell A, Åkesson G, et al. Possible reasons why female physicians publish fewer scientific articles than male physicians-a cross-sectional study. BMCMed Educ2015;15:67.

14. Del Boca FK. Addressing sex and gender inequities in scientificresearchand publishing. Addiction 2016;111(8):1323-5.

15. Organización Internacional del Trabajo. Las mujeres en el trabajo. Tendencias 2016. Resumen ejecutivo. Ginebra, 2016. [Accessed on: April 4 ${ }^{\text {th }}$ 2017]. Available at: http:// www.unesco.org/library/PDF/wcms_457094.pdf

\title{
Strategies for compliance with the internship program among three pediatric interns with latex allergy
}

\author{
Stefanía Barbariol, M.D., ${ }^{a}$ Alfredo Eymann, M.D. ${ }^{b, c}$ Julián Llera, M.D. ${ }^{c}$ and Claudio A. Parisi, M.D. ${ }^{a}$
}

\begin{abstract}
Introduction. Latex allergy is common in the hospital setting. Objective. To describe the clinical situation of three pediatric interns with latex allergy and the prevention strategies implemented during clinical clerkships in pediatric and neonatal intensive care units.

Patients, methods, and outcomes. The three interns referred symptom exacerbation during their internship program. Diagnosis was confirmed based on a compatible history and positive specific immunoglobulin E. A semi-structured interview was done to describe perceptions about prevention strategies, the personnel were trained, and nitrile gloves were provided for carrying out procedures. Interns completed their clinical clerkships without having allergic reactions. Positive aspects referred by interns were that they felt cared for and experienced an improved quality of life; negative aspects were a bad predisposition and resistance against change among some other interns. Strategies designed to this end permitted interns to continue their internship program.
\end{abstract}

a. Division of Allergy of the Department of Clinical Pediatrics of Hospital Italiano de Buenos Aires, Buenos Aires, Argentina.

b. Post-Graduate Education Department of Instituto Universitario del Hospital Italiano de Buenos Aires, Buenos Aires, Argentina.

c. Department of Clinical Pediatrics of Hospital Italiano de Buenos Aires, Buenos Aires, Argentina.

E-mail address:

Claudio A. Parisi, M.D.: claudio.parisi@hospitalitaliano.org.ar

Funding: None.

Conflict of interest: None.

Received: 2-28-2017

Accepted: 6-28-2017
Key words: latex allergy, medical internship program, prevention, health care providers.

http:/ / dx.doi.org/10.5546/ aap.2017.eng.583

To cite: Barbariol S, Eymann A, Llera J, et al. Strategies for compliance with the internship program among three pediatric interns with latex allergy. Arch Argent Pediatr 2017;115(6):583-587.

\section{INTRODUCTION}

Latex allergy was first described in Germany in $1927 .{ }^{1}$ As of the 1980 s, the number of case reports increased notably, mainly due to three factors: a) massive use of latex gloves to prevent disease transmission, $b$ ) reduced production quality with an increase in protein content, and c) replacement of talc powder with cornstarch powder to prevent granuloma formation.

Frequent use of latex gloves in closed areas, e.g. operating theaters, generates a high density atmosphere of cornstarch particles, and, because of their high molecular weight, smaller particles, such as latex, tend to adhere onto their surface and are carried away. ${ }^{2}$

Clinical manifestations vary depending on the route of exposure: they may range from mild effects, such as contact urticaria or rhinoconjuntivitis, to severe ones, e.g. anaphylaxis. ${ }^{3}$

The internship program is a professional socialization system that helps, through an 
immersion strategy, young health care providers take over the values, rules, practices, and knowledge of the group to which they wish to belong, thereby allowing recently graduated interns to become expert physicians. ${ }^{4}$

Internships include learning practices and procedures that, for the sake of biosafety, require wearing latex material. The risk for allergy increases in the settings with a high rate of procedures, such as pediatric or neonatal intensive care units.

It is reasonable to adopt preventive measures among people with latex sensitization or allergy who, because of the characteristics of their training curriculum, should be exposed to latex. ${ }^{5}$

\section{OBJECTIVE}

To describe the clinical situation of pediatric interns with latex allergy and the prevention strategies implemented during clinical clerkships in pediatric and neonatal intensive care units.

\section{PATIENTS, METHODS AND OUTCOMES}

Here we describe the case of three pediatric interns diagnosed with latex allergy (Table 1).

Latex allergy was defined based on a history compatible with immediate type I hypersensitivity reaction accompanied with positive specific immunoglobulin E (IgE) obtained by patch and/or serum testing with an immediate reading. ${ }^{6}$
The patch test was done following international guidelines. ${ }^{7}$ Natural latex extract $\left(\right.$ Allergopharma ${ }^{\circledR}$ ) was used and punctures were done using Diater ${ }^{\circledR}$ metal lancets. A papule size larger than $3 \mathrm{~mm}$ compared to the negative control was considered positive. Specific IgE serum levels for latex were obtained from serum samples. Measurements were made using an enzyme-linked immunosorbent assay (ELISA), Capture Assay Radim Liquid Allergens (CARLA) method.

Five meetings were held to discuss the study, review the bibliography, and design prevention strategies with the director of the internship program, 2 chief residents, the head of the pediatric intensive care unit, the head of the PostGraduate Education Department, and the head of the Division of Allergy.

When a member of the health care staff has latex allergy, the proposed strategies may be activity limitation or adaptation (including the reduction of latex proteins in the environment, wearing latex-free gloves, and education for the rest of the health care team members about the importance of a latex-free environment) or a change in the work place (i.e., changing their work place to a totally latex-free environment). ${ }^{8}$

Staff members were trained to define the clinical situation and provide training on prevention strategies; nitrile gloves were to be

TABLE 1. Clinical characteristics of the interns with latex allergy

\begin{tabular}{|c|c|c|c|c|c|c|c|}
\hline Case & Age & History & $\begin{array}{l}\text { History } \\
\text { of allergy }\end{array}$ & $\begin{array}{l}\text { Symptom } \\
\text { initiation } \\
\text { during } \\
\text { the program }\end{array}$ & $\begin{array}{l}\text { Symptoms } \\
\text { during } \\
\text { the program }\end{array}$ & $\begin{array}{c}\text { RAST } \\
\text { (ELISA) }\end{array}$ & $\begin{array}{l}\text { Patch } \\
\text { test;. } \\
\text { papule } \\
\text { size }\end{array}$ \\
\hline 1 & 29 & $\begin{array}{l}\text { Adenotonsillectomy. } \\
\text { Asthma }\end{array}$ & $\begin{array}{l}\text { Allergic rhinitis. } \\
\text { Lip edema } \\
\text { at the dentist. } \\
\text { Erythema and pruritus } \\
\text { when using condoms }\end{array}$ & $\begin{array}{l}\text { First year } \\
\text { is } \\
\end{array}$ & $\begin{array}{l}\text { Dermatitis and } \\
\text { erythema on } \\
\text { the hands } \\
\text { when wearing } \\
\text { gloves }\end{array}$ & $0.97 \mathrm{IU} / \mathrm{ml}$ & $5 \mathrm{~mm}$ \\
\hline 2 & 30 & Peritonitis & $\begin{array}{l}\text { Allergic rhinitis. } \\
\text { Erythema and pruritus } \\
\text { when using condoms. } \\
\text { Lip edema when } \\
\text { blowing up balloons }\end{array}$ & First year & $\begin{array}{l}\text { Dermatitis and } \\
\text { erythema on } \\
\text { the hands } \\
\text { when wearing } \\
\text { gloves }\end{array}$ & $\begin{array}{c}\text { Less than } \\
0.36 \mathrm{IU} / \mathrm{ml}\end{array}$ & $4 \mathrm{~mm}$ \\
\hline 3 & 27 & $\begin{array}{l}\text { Adenotonsillectomy. } \\
\text { Reconstructive surgeries } \\
\text { due to an accident (9). } \\
\text { Asthma. } \\
\text { Atopic dermatitis }\end{array}$ & $\begin{array}{l}\text { Allergic rhinitis. } \\
\text { Asthma. } \\
\text { Lip edema } \\
\text { at the dentist. } \\
\text { Erythema and pruritus } \\
\text { when using condoms }\end{array}$ & $\begin{array}{l}\text { Second year } \\
\text { is }\end{array}$ & $\begin{array}{l}\text { Dermatitis and } \\
\text { erythema on } \\
\text { the hands } \\
\text { when wearing } \\
\text { and asthma } \\
\text { exacerbation }\end{array}$ & $\begin{array}{c}\text { Less than } \\
0.36 \mathrm{IU} / \mathrm{ml}\end{array}$ & $4 \mathrm{~mm}$ \\
\hline
\end{tabular}

RAST: radioallergosorbent test; ELISA: enzyme-linked immunosorbent assay. 
used for all procedures conducted in the pediatric and neonatal intensive care units. A second training session was required for 4 members of the health care team who did not understand or did not agree to modify their behavior in relation to wearing latex material.

The diagnosis of latex allergy diagnosis was confirmed in the 3 interns (Table 1); strategies designed to this end were communicated, and the agreement and consent to perform the clinical clerkships were obtained from them. Finally, a survey was administered so that the interns could describe their perceptions about the implemented care strategies.

The following outcome measures were analyzed: positive and negative aspects of implemented strategies, fears or worries among the rest of the interns and in relation to their professional development.

\section{RESULTS}

The 3 interns completed 8 months of clinical clerkship in pediatric and neonatal intensive care units (4 months in each unit) and showed no allergic manifestations.

They perceived the following as positive aspects of the strategies designed to this end: "feeling cared for," "improved quality of life," "involvement of the rest of the health care staff with this issue," "positive feelings about the initiation of a long path towards raising awareness," and "measures taken to this end."

The following negative aspects were noted: "bad predisposition towards new measures and resistance against change among some interns," "insufficient availability of different sizes of sterile gloves," "not all sectors fully comply with measures taken." In addition, the following fears or worries were perceived at a professional level: "accidental exposure in other hospital areas," "increasingly more severe symptoms due to exposure," "lack of awareness in the hospital itself." Lastly, the following fears or worries were perceived at a personal level: "development of new allergies," "having medical or dental checkups," "accidental exposure in out-of-hospital settings."

\section{DISCUSSION}

Latex allergy is an increasingly relevant health problem, and strategies developed to this end allowed interns to complete their training clinical clerkships.

In Argentina, there are 117 pediatric internships and residency programs that last approximately 3 to 4 years. In all curricula, procedures that require coming into contact with latex products are included. ${ }^{10}$

Obtaining the patient's case history and the suspicion index are still the main diagnostic elements. When latex allergy is clinically suspected, the patient should be referred to an allergy specialist to have the necessary diagnostic tests done and his/her risk classified. ${ }^{11}$

Patch tests are convenient, provide immediate results, and are inexpensive compared to in vitro tests, therefore, they are considered the gold standard for the diagnosis of latex allergy. ${ }^{12}$ Patch tests using latex or the right latex extracts provide a sensitivity and a specificity close to $100 \% .{ }^{13}$

For people with latex allergy, prevention plays a key role; however, the extensive use of latex has turned such prevention into a highly complex task. One of the populations at highest risk are health care workers; according to international studies, approximately $3-17 \%$ of them have latex sensitization. ${ }^{14,15}$

Health care workers with latex allergy may be forced to leave their work setting or, as in the cases analyzed here, implement measures within their work place to establish a safe setting. As a primary prevention measure, it has been demonstrated that wearing powder-free or lowprotein content gloves reduces latex sensitization, the number of symptoms, and specific IgE levels. ${ }^{15}$

Although published studies have supported the effectiveness of secondary prevention protocols among high-risk patients with latex allergy, ${ }^{11}$ to date no measures have been designed within the context of an internship program with interns who have latex allergy. This study stands as an alternative to reflect on this problematic issue.

The proposed strategies were aimed at establishing a low-latex content environment, which was sufficient to meet the objective.

Given the increase in the number of health care workers and patients with latex allergy, it is important to establish safe environments or with a low latex content in hospitals.

In Argentina, there are still no hospitals that favor the development of training programs and warrant the safety of patients with latex allergy. In this case, interns stated that they felt supported by the internship system and many of the other interns during clinical clerkships; however, there are still resistance and fear in relation to their future development. 
The commitment of every individual responsible for the training process was a key element to design prevention strategies. This is a growing health problem with potentially legal health care implications so it should be considered an interdisciplinary problem ${ }^{1}$ that will require new scenarios for the development of inclusive training programs that warrant learning opportunities for all health care workers and providers with latex allergy.

\section{Acknowledgments}

We would like to thank Nicolás Onna, M.D., and Danila Labonia, M.D., for their collaboration.

\section{REFERENCES}

1. Stern G. Überempfindlichkeit gegen kautschuk als ursache von urticaria und quinckeschem ödem. KlinWochenschr 1927;6:1096-7.

2. Hamilton RG, Adkinson NF Jr. Diagnosis of natural rubber latex allergy: multicenter latex skin testing efficacy study. Multicenter Latex Skin Testing Study Task Force. J Allergy ClinImmunol 1998;102(3):482-90.

3. Anda M, Gómez B, Lasa E, et al. Alergia al látex. Manifestaciones clínicas en la población general y reactividad cruzada con alimentos. An Sist Sanit Navar 2003;26(Suppl 2):75-80.

4. Malamud I. Notas para la evaluación del sistema de residencias médicas. Rev Hosp Ital BAires 2008;28(2):71-4.

5. Merget R, van Kampen V, Sucker K, et al. The German experience 10 years after the latex allergy epidemic: need for further preventive measures in healthcare employees with latexallergy. Int Arch Occup Environ Health 2010;83(8):895-903.

6. Cabañes N, IgeaJM, dela Hoz B, etal. Latex Allergy: Position Paper. J Investig Allergol ClinImmunol 2012;22(5):313-30.

7. Bózzola CM. Pruebas cutáneas de lectura inmediata. Técnica, lectura e interpretación. Arch Alerg Inmunol Clin 2002;33(Supl 2):S51-7.

8. Monduzzi G, Franco G. Practising evidence-based occupational health in individual workers: how to deal with a latex allergy problem in a health care setting. Occup Med (Lond) 2005;55(1):3-6.

9. Sociedad Argentina de Pediatría. Consejo de Acreditación de Espacios de Formación CAEF. [Accessed on: June 30 ${ }^{\text {th }}$, 2017]. Available at: http://www.sap.org.ar/docs/caef/ ListadoResidenciasAcreditadas2016.pdf.

10. Duré I. Residencias del equipo de salud. Documento marco 2011. Ministerio de Salud [Accessed on: June $30^{\text {th }}$, 2017]. Availableat:http:/ / www.msal.gov.ar/residencias / images / stories / descargas / queEs / Documento_Marco_ Residencias_OK.pdf.

11. Parisi CA, B Biló, Bonifazzi F, et al. Alergia al latex. Arch Argent Pediatr 2006;104(6):520-9.

12. Buss ZS, KupekE, Fröde TS. Screening for latex sensitization by questionnaire: diagnostic performance in health care workers. J Investig Allergol Clin Immunol 2008;18(1):12-6.

13. Turjanmaa K, Reunala T, Räsänen L. Comparison of diagnostic methods in latex surgical glove contact urticaria. Contact dermatitis 1988;19(4):241-7.

14. Sussman GL, Lem D, Liss G, et al. Latex allergy in housekeeping personnel. Ann Allergy Asthma Immunol 1995;74(5):415-8.

15. Yassin MS, Lierl MB, Fischer TJ, et al. Latex allergy in hospital employees. Ann Allergy 1994;72(3):245-9. 